\title{
Immunohistochemical Analysis of Cell Proliferation and Suppression of Ameloblastoma with Special Reference to Plexiform and Follicular Ameloblastoma
}

\author{
Toryu Hirayama ${ }^{1,2}$, Tomofumi Hamada ${ }^{1}$, Kazuhisa Hasui $^{2}$, Ichiro Semba ${ }^{3}$, \\ Fusayoshi Murata $^{2}$ and Kazumasa Sugihara ${ }^{1}$

\begin{abstract}
${ }^{1}$ Department of Maxillofacial Diagnostic and Surgical Sciences, Field of Oral and Maxillofacial Rehabilitation, Kagoshima University Graduate School of Medical and Dental Sciences, Kagoshima, Japan, ${ }^{2}$ Department of Structural Cell Biology, Field of Neuro-Musculoskeletal Disorder, Kagoshima University Graduate School of Medical and Dental Sciences, Kagoshima, Japan and ${ }^{3}$ Department of Oral Pathology, Field of Oncology, Kagoshima University Graduate School of Medical and Dental Sciences, Kagoshima, Japan
\end{abstract}

Received December 16, 2004; accepted January 12, 2005

To understand proliferation and suppression in ameloblastoma that exhibit locally invasive growth and recur clinically, the expression of proliferating cell nuclear antigen (PCNA), Ki-67 antigen, topoisomerase Il $\alpha$, p53 and p21 proteins were analyzed with immunohistochemistry. Sections of archival ameloblastoma tissues were used (16 plexiform and 14 follicular types). Each antigen was labeled by the polymer method with optimal antigen retrieval. The plexiform type exhibited higher expression of PCNA, Ki67 and topoisomerase II $\alpha$ antigens than the follicular type. Expression of PCNA correlated significantly with that of the Ki-67 antigen. The plexiform type also exhibited greater expression of p53 and p21 proteins than the follicular type. Expression of p53 protein correlated significantly with that of p21, PCNA, Ki-67 antigen and topoisomerase II $\alpha$. Expression of p21 protein did not correlate with that of the proliferation-related antigens. These findings suggest that the plexiform ameloblastoma has higher proliferating activity and malignant potentiality as neoplastic cells than the follicular ameloblastoma.

Key words: ameloblastoma, PCNA, Ki-67, topoisomerase Il $\alpha$, p53

\section{Introduction}

Ameloblastoma is the most common benign tumor arising in the odontogenic epithelium. This tumor exhibits slow invasive growth and relatively high rate of recurrence. Histology of the ameloblastoma is subcategorized into follicular, plexiform, granular cell, acanthomatous, and basal cell types according to the WHO classification in 1992 [10], although the plexiform and follicular types are predominant. The plexiform type reveals enlarging cystic lesions in the stroma. The follicular type exhibits many islands of tumor cells in fibrous stromal tissue. According to Reichart et al. [21] these two major types account for $64.1 \%$ of 693

Correspondence to: Toryu Hirayama, D.D.S., Department of Maxillofacial Diagnostic and Surgical Sciences, Field of Oral and Maxillofacial Rehabilitation, Kagoshima University Graduate School of Medical and Dental Sciences, 8-35-1 Sakuragaoka, Kagoshima 890-8544, Japan. E-mail: toryu-h@denta.hal.kagoshima-u.ac.jp ameloblastomas. The biological differences between neoplastic cells of these two major types have yet to be fully elucidated.

Expression of cell-proliferating markers, such as proliferating cell nuclear antigen (PCNA), Ki-67 antigen and topoisomerase II $\alpha$, has been investigated by immunohistochemical means (IHC) to predict the biological behavior of neoplastic cells in various types of ameloblastoma. Funaoka et al. [2], Ong'uti et al. [19] and Sandra et al. [22] have reported that labeling indices of PCNA and Ki-67 antigen were higher in the follicular compared with the plexiform type. By contrast, Kim and Yook [8] and Piattelli et al. [20] reported contrary findings. Kumamoto et al. [12] introduced IHC with the anti-topoisomerase II $\alpha$ antibody to detect proliferating cells in ameloblastoma. However, the proliferation of neoplastic cells in these two types has yet to be fully elucidated.

Expression of cell proliferation suppression genes in ameloblastomas has been also studied. Mutations in the p53 
protein gene have reported in odontogenic epithelial lesions including ameloblastoma by Slootweg [28]. Kumamoto suggested that, paradoxically in ameloblastoma, the expression of p53 protein reflected the proliferation activity of neoplastic cells, rather than apoptosis [11]. Furthermore, they demonstrated that in odontogenic epithelium, p21 protein expression correlated with cell differentiation and apoptosis [9, 12]. Sandros et al. [24] proposed that expression of the $\mathrm{p} 21$ gene could be an index in predicting the biological behavior of ameloblastoma.

In this study, we analyzed the cell proliferation and proliferation suppression in neoplastic cells of plexiform and follicular ameloblastomas by means of IHC, using monoclonal antibodies against PCNA, Ki-67 antigen, topoisomerase II $\alpha$, p53 protein and p21 protein on sections of archival specimens of ameloblastomas.

\section{Materials and Methods}

Routinely-processed, archival specimens of ameloblastomas surgically removed from 30 patients at Kagoshima University Hospital (The Department of Oral Surgery), between 1988 and 2004, were used for this study.

The patients with the ameloblastomas consisted of 21 men and 9 women, and their age ranged from 12 to 94 years old (mean age: 43 years old), as presented in Table 1. Ameloblastoma occurred in the maxilla in six cases $(20 \%)$ and in the mandible in 24 cases $(80 \%)$, comprising 26 primary cases $(87 \%)$ and four recurrent cases $(13 \%)$. Based on clinical appearance, these cases were 15 of the solid type $(50 \%), 11$ of the cystic type (37\%), and 4 of the mixed type $(13 \%)$. According to the 2 nd edition of the WHO classification of odontogenic tumors [10], 16 cases (53\%) were diag-

Table 1. Clinicopathological factors of 30 patients with ameloblastoma

\begin{tabular}{|c|c|c|c|}
\hline \multirow{2}{*}{ Factor } & \multicolumn{2}{|c|}{ Histological classification } & \multirow{2}{*}{ Total } \\
\hline & Plexiform & Follicular & \\
\hline \multicolumn{4}{|l|}{ Sex } \\
\hline Male & 12 & 9 & 21 \\
\hline Female & 4 & 5 & 9 \\
\hline \multicolumn{4}{|l|}{ Age } \\
\hline Young $(\sim 20)$ & 5 & 3 & 8 \\
\hline Middle (21 40) & 3 & 3 & 6 \\
\hline Old $(41 \sim)$ & 8 & 8 & 16 \\
\hline \multicolumn{4}{|l|}{ Location } \\
\hline Maxilla & 3 & 3 & 6 \\
\hline Mandible & 13 & 11 & 24 \\
\hline \multicolumn{4}{|l|}{ Recurrence } \\
\hline Primary case & 13 & 13 & 26 \\
\hline Recurrence case & 3 & 1 & 4 \\
\hline \multicolumn{4}{|l|}{ Clinical appearance } \\
\hline Solid type & 6 & 9 & 15 \\
\hline Cystic type & 7 & 4 & 11 \\
\hline Mixed type & 3 & 1 & 4 \\
\hline
\end{tabular}

nosed as the plexiform type and 14 cases $(47 \%)$ were of the follicular type.

This study was performed with the approval of the ethical committee for the clinical studies, Kagoshima University Hospital (16-21, July, 5, 2004).

\section{Immunohistochemistry (IHC) of anti-PCNA, Ki-67 antibodies, topoisomerase II $\alpha$, p53 protein and p21 protein antibodies}

Four $\mu \mathrm{m}$ thick sections of the archival, paraffin-embedded ameloblastoma tissues, adhered to silane-coated glass slides were used. After baking sections at $60^{\circ} \mathrm{C}$ for more than $30 \mathrm{~min}$, sections were deparaffinized and immersed in methanol with $0.3 \%$ hydrogen peroxide to inhibit the activity of endogenous peroxidases. Antigen retrieval was performed by incubating sections in $0.01 \mathrm{M}$ citrate buffer $(\mathrm{pH}$ 6.0) and heating at $121^{\circ} \mathrm{C}$ for $10 \mathrm{~min}$ in an autoclave. For the antigen retrieval for the IHC of the anti-PCNA antibody, sections were immersed in distilled water and were heated for $10 \mathrm{~min}$ using a microwave $(500 \mathrm{~W})$ [13]. After sufficient cooling, sections were rinsed 3 times for $5 \mathrm{~min}$ each with phosphate buffered saline (PBS). After blocking non-specific reactions by incubating sections in a non-specific staining blocking reagent (Protein Block, X0909, DakoCytomation Glostrup Denmark) for $10 \mathrm{~min}$, sections were incubated with one of the primary antibody solutions for $1 \mathrm{hr}$. The solutions of the primary antibodies were as follows: mouse monoclonal anti-PCNA antibody solution (DakoCytomation, PC10, 1:150), mouse monoclonal anti-Ki-67 antigen antibody (DakoCytomation, MIB-1, 1:100), mouse monoclonal antitopoisomerase II $\alpha$ antibody (DakoCytomation, SWT3D1, 1:100), mouse monoclonal anti-p53 antibody (DakoCytomation, DO-7, 1:50) and mouse monoclonal anti-p21 antibody (DakoCytomation, SX118, 1:50) (Table 2). The primary antibodies were visualized by means of ChemMate ENVISION/HRP system (K5007, DakoCytomation, Glostrup, Denmark) and 3,3'-diaminobenzidine tetrahydrochloride liquid system (K3468, DakoCytomation, Glostrup, Denmark) for $5 \mathrm{~min}$. Nuclei were counterstained with ChemMate hematoxylin (S2020, DakoCytomation, Glostrup, Denmark) for $3 \mathrm{~min}$. After dehydration, the sections were mounted

Table 2. Monoclonal antibodies used for immunohistochemistry in ameloblastoma

\begin{tabular}{|c|c|c|c|}
\hline Antibody & Source & Dilution & $\begin{array}{l}\text { Antigen retrieval } \\
\text { treatment }\end{array}$ \\
\hline anti-PCNA & Dako*, PC-10 & $1: 150$ & $\begin{array}{l}\text { Microwave } \\
(500 \mathrm{~W}, 10 \mathrm{~min})\end{array}$ \\
\hline anti-Ki-67 & Dako*, MIB-1 & $1: 100$ & $\begin{array}{l}\text { Autoclave } \\
\left(121^{\circ} \mathrm{C}, 10 \mathrm{~min}\right)\end{array}$ \\
\hline $\begin{array}{l}\text { anti-Topoisomerase } \\
\text { II } \alpha\end{array}$ & Dako*, SWT3D1 & $1: 100$ & $\begin{array}{l}\text { Autoclave } \\
\left(121^{\circ} \mathrm{C}, 10 \mathrm{~min}\right)\end{array}$ \\
\hline anti-p53 & Dako*, DO-7 & $1: 50$ & $\begin{array}{l}\text { Autoclave } \\
\left(121^{\circ} \mathrm{C}, 10 \mathrm{~min}\right)\end{array}$ \\
\hline anti-p21 & Dako*, SX118 & $1: 50$ & $\begin{array}{l}\text { Autoclave } \\
\left(121^{\circ} \mathrm{C}, 10 \mathrm{~min}\right)\end{array}$ \\
\hline
\end{tabular}

* Glostrup, Denmark 
in a plastic medium.

The processes after the antigen retrieval were performed using an autostainer (Dako autostainer, DakoCytomation, Glostrup Denmark), in which washing buffer was warmed at $35^{\circ} \mathrm{C}$ in a water bath.

Sections of oral mucosa bordering ameloblastoma and squamous cell carcinoma (SCC) were used as positive controls, to determine whether the above-mentioned IHC of anti-PCNA, Ki-67 antibodies, topoisomerase II $\alpha$, p53 protein and p21 protein antibodies were able to label the target antigens in squamous cells. For a negative control, PBS was applied in substitution for the primary antibody.

\section{Labeling indices of anti-PCNA, Ki-67 antigen, topoisomerase II $\alpha$, p3 protein and 21 protein antibodies}

Using the $40 \times$ objective magnification of a microscope (BX41, Olympus Japan) equipped with a digital camera (DP70, Olympus Japan), microphotographs were taken of 5 randomly selected areas in each immunostained section, where numerous neoplastic cells of ameloblastoma were observed. Identifying neoplastic cells as peripheral cuboidal, columnar, central polyhedral and stellate-like cells on the microphotos, the neoplastic cells exhibiting clearly browncolored nuclei were counted by two independent examiners, as cells labeled by the primary antibody. One thousand neoplastic cells were counted in each section. The labeling index of each antibody was calculated for each field, according to the previously described methods of Sandra et al. [22].

\section{Statistical analysis of labeling indices}

Mean and standard deviation (S.D.) were calculated for the labeling indices of PCNA and Ki-67, topoisomerase II $\alpha$, p53, and p21 in all of the cases according to the histological subtypes of ameloblastoma. Mann-Whitney's U-test was used to test whether there were significant differences in the labeling indices between plexiform and follicular types.

For evaluation of the expression of cell-proliferation suppressor gene products, ameloblastomas were categorized in cases of high or low expression. In the evaluation of p53 protein, in cases in which more than $15 \%$ neoplastic cells were labeled, the expression was judged as tentatively high, whereas in other cases the expression was judged low. For the evaluation of $\mathrm{p} 21$ protein, in cases in which more than $5 \%$ neoplastic cells were labeled, expression was evaluated as tentatively high, and in other cases the expression considered low. Fisher's exact probability test was used to determine whether there was any significant differences in the expression of p53 and p21 proteins between the plexiform and follicular types.

Correlation between the crude labeling indices of the antibodies was examined by using Pearson's correlation coefficient. In grading the labeling indices of p53 and p21 proteins as low or high expression, Mann-Whitney's U-test was also employed to demonstrate any correlation among the labeling indices.

\section{Results}

\section{Proliferation activity of neoplastic cells in ameloblastomas}

PCNA labeled many nuclei of neoplastic cells in ameloblastoma, as demonstrated in Figures $1 \mathrm{C} \&$ D. This antibody labeled nuclei of some basal and most parabasal and prickle cells, though keratinized cells were not labeled in oral stratified squamous epithelia (Fig. 1A) and most nuclei of SCC cells (Fig. 1B). PCNA-labeled nuclei of the neoplastic cells decreased gradually from the outer part to the inner part of the alveoli in the plexiform type (Fig. 1C), whereas those located dominantly in the palisading neoplastic cells of the alveoli were of the follicular type (Fig. 1D). As demonstrated in Table 3, the labeling index of PCNA in neoplastic cells of ameloblastomas was $18.8 \pm 16.5 \%$, overall, and was higher in the plexiform type $(21.4 \pm 16.4 \%)$ than in the follicular type $(15.9 \pm 17.3 \%)$.

The Ki-67 antigen was found in a smaller number of nuclei of neoplastic cells in ameloblastomas than PCNA. Neoplastic cells exhibiting nuclei with the Ki-67 antigen were located in the outer part of the alveoli in the plexiform type (Fig. 1G) and in the palisading cell layer of the alveoli in the follicular type (Fig. 1H). The squamous cells exhibiting nuclei with the Ki-67 antigen were observed, keratinized cells were not labeled in the basal and parabasal layers of the stratified squamous epithelia (Fig. 1E), whereas most nuclei of SCC cells exhibited the Ki-67 antigen (Fig. 1F). The labeling index of Ki-67 antigen in the neoplastic cells of ameloblastoma (Table 3 ) was $8.2 \pm 5.3 \%$ overall, and was higher in the plexiform type $(9.6 \pm 5.6 \%)$ than in the follicular type $(6.5 \pm 4.8 \%)$.

Topoisomerase II $\alpha$ was evident in a smaller number of nuclei of neoplastic cells than PCNA. Neoplastic cells demonstrating nuclei with topoisomerase II $\alpha$ exhibited almost the same distribution in the alveoli as those exhibiting nuclei with Ki-67 antigen (Fig. 1K). In some cases of the follicular type, numerous nuclei with topoisomerase II $\alpha$ were noted in the palisading cell layer (Fig. 1L). The labeling index of topoisomerase II $\alpha$ in the neoplastic cells (Table 3) was $8.8 \pm 11.8 \%$, and was significantly higher in the plexiform type $(11.9 \pm 15.3 \%)$ than in the follicular type $(5.2 \pm 5.1 \%)$ $(\mathrm{p}=0.026)$.

The labeling indices of PCNA and Ki-67 antigen indicated significant correlation (Pearson's correlation coefficient, $\mathrm{r}=0.685, \mathrm{p}=0.0001$ ), but that of topoisomerase II $\alpha$ did not correlate with those of PCNA and Ki-67 antigens (Table $5)$.

The relationship between clinicopathological factors and the labeling indices of PCNA, Ki-67 antigen and topoisomerase II $\alpha$ exhibited the following tendencies (Table 6). In grading the age of patients as young (under 20 years old), middle-aged (over 21 years old) and elderly (over 41 years old), the labeling indices of PCNA and Ki-67 antigen were higher in the young people than in the elderly, whereas the the labeling index of topoisomerase II $\alpha$ was lower in the young people than in the elderly. The recurrent ameloblastomas indicated higher labeling indices of PCNA, Ki-67 anti- 
Oral mucosa
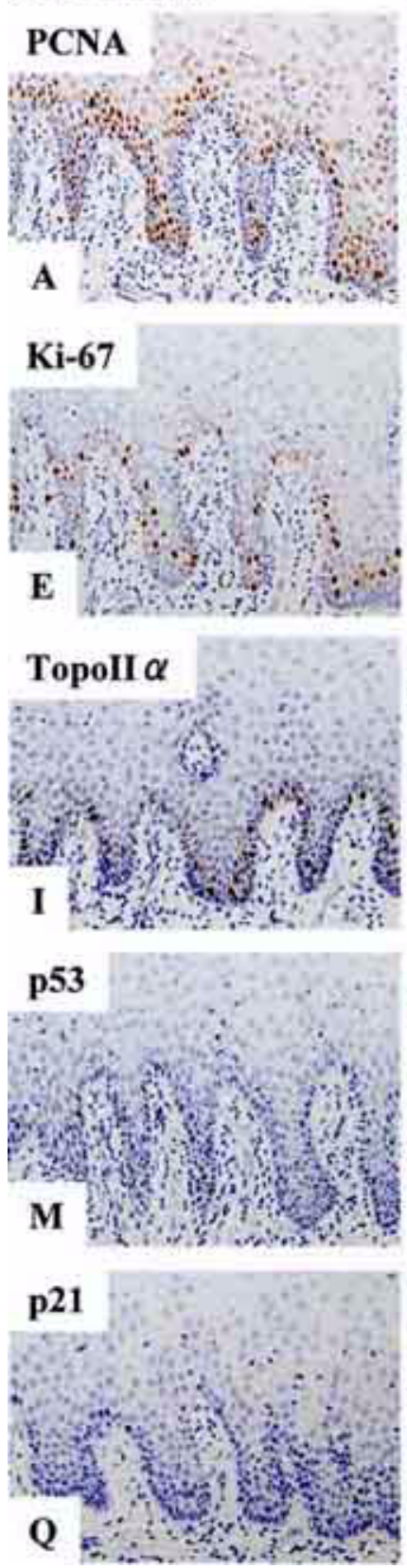

\section{Squamous cell carcinoma Plexiform}
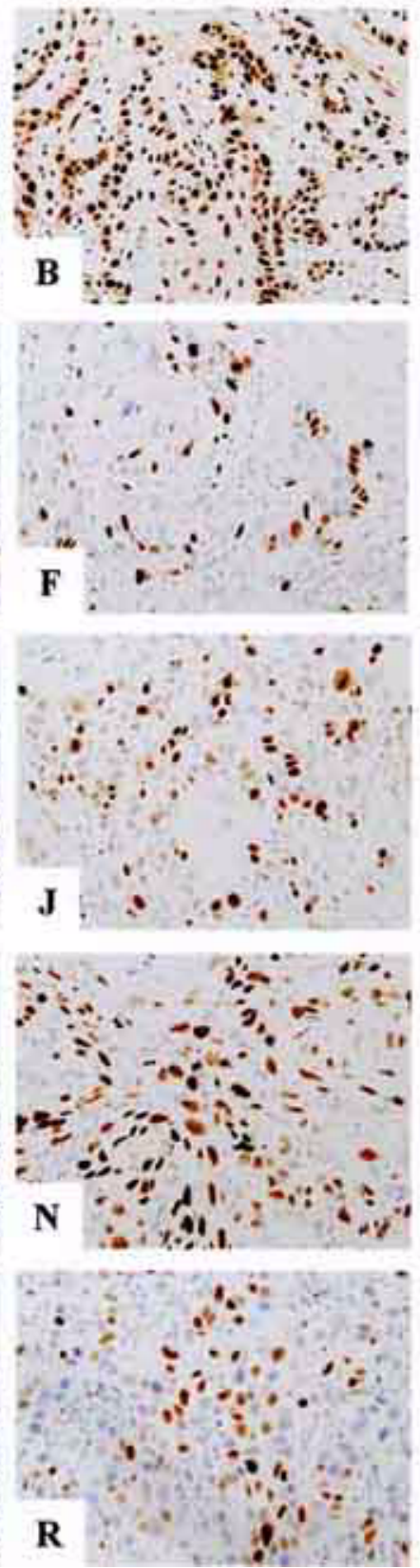
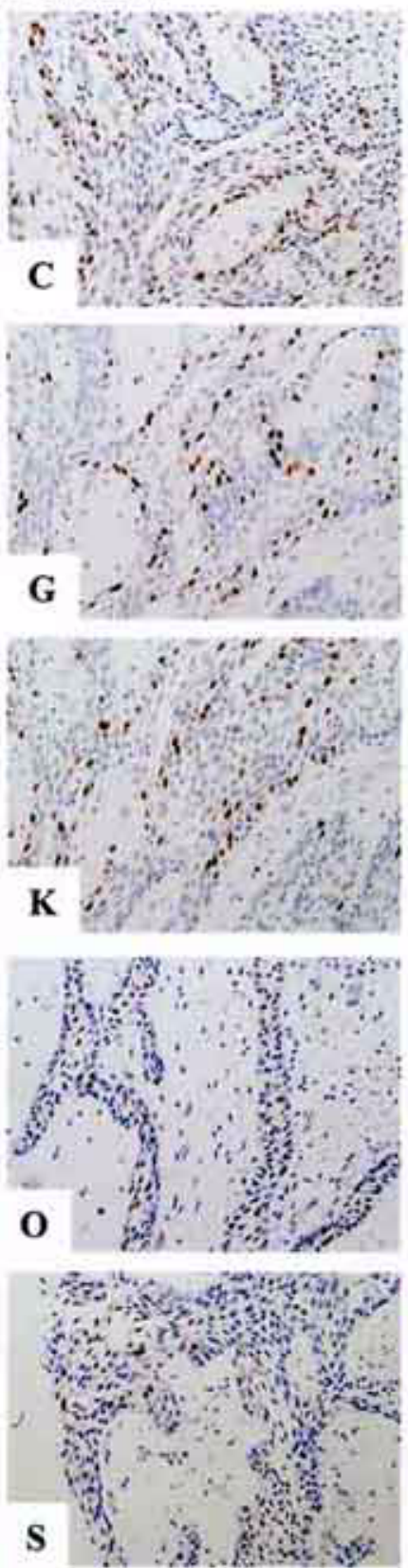

Follicular
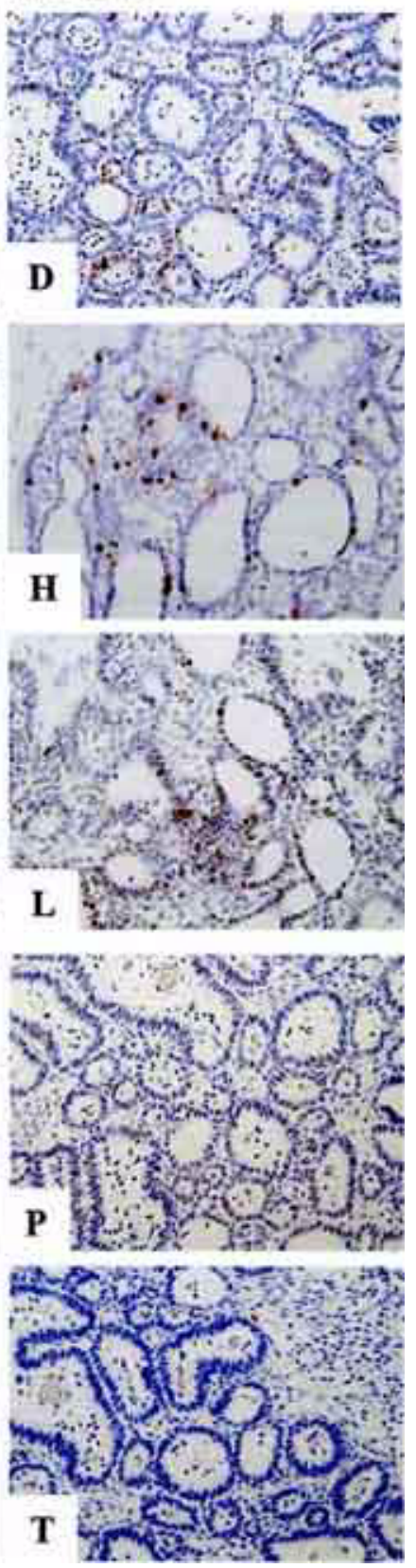

Fig. 1. Nuclei from many basal cells were labeled specifically in oral mucosa with cell-proliferation markers; specifically, the nuclei of many basal cells in the oral mucosa (A, E, I). In squamous cell carcinoma, those labeled nuclei of neoplastic cells were scattered in the foci $(\mathbf{B}, \mathbf{F}, \mathbf{J})$. In ameloblastoma, labeled cells were observed in the outer part to the inner part of the alveoli in the plexiform type $(\mathbf{C}, \mathbf{G}, \mathbf{K})$, whereas many labeled cells were discernible in the palisading neoplastic cells layer of the alveoli in the follicular type $(\mathbf{D}, \mathbf{H}, \mathbf{L})$. Antibodies against the cell cycle suppressor gene products were detected in a few basal cells in the oral mucosa $(\mathbf{M}, \mathbf{Q})$. Numerous neoplastic cells were detected in squamous cell carcinoma $(\mathbf{N}, \mathbf{R})$. In ameloblastoma, neoplastic cells were stained in the inner layer of the alveoli in the plexiform $(\mathbf{O}, \mathbf{S})$ and follicular types $(\mathbf{P}, \mathbf{T})$.

gen and topoisomerase II $\alpha$ than the primary cases. The ameloblastomas indicated higher labeling indices of PCNA, $\mathrm{Ki}-67$ and topoisomerase II $\alpha$ in the mandible than in the maxilla. The cystic ameloblastoma indicated higher labeling indices of PCNA and Ki-67 antigen than the solid type
(Table 6).

\section{Expression of cell-proliferation suppressor gene products}

Expression of p53 protein was detected in 24 cases $(80 \%)$ overall, 13 cases $(43 \%)$ in the plexiform type and 11 
Table 3. Labeling indices of plexiform and follicular ameloblastoma

\begin{tabular}{|c|c|c|c|c|c|c|}
\hline \multirow{3}{*}{ Classification } & \multirow{3}{*}{ No. of cases } & \multicolumn{5}{|c|}{ Labeling-index mean \pm S.D. (\%) } \\
\hline & & \multicolumn{5}{|c|}{ Range (\%) } \\
\hline & & PCNA & $\mathrm{Ki}-67$ & Topo II $\alpha$ & $\mathrm{p} 53$ & $\mathrm{p} 21$ \\
\hline \multirow[t]{2}{*}{ Plexiform } & 16 & $21.4 \pm 16.4$ & $9.6 \pm 5.6$ & $11.9 \pm 15.3$ & $12.5 \pm 13.1$ & $5.3 \pm 8.2$ \\
\hline & & $0-63.4$ & $2.3-19.8$ & $0.9-54.2$ & $0-36.5$ & $0-25.0$ \\
\hline \multirow[t]{2}{*}{ Follicular } & 14 & $15.9 \pm 17.3$ & $6.5 \pm 4.8$ & $5.2 \pm 5.1$ & $4.7 \pm 5.1$ & $2.3 \pm 3.5$ \\
\hline & & $2.1-57.6$ & $1.6-17.6$ & $1.6-21.2$ & $0-17.0$ & $0-12.2$ \\
\hline
\end{tabular}

Labeling-index: Positive cell/1000 tumor cells $\times 100(\%)$

* Mann-Whitney's U-test $(\mathrm{p}=0.026)$

Significant differences: $\mathrm{p}<0.05$

Table 4. Labeling indices of cell proliferating suppressor gene in ameloblastoma

\begin{tabular}{|c|c|c|c|c|}
\hline \multirow{2}{*}{ Classification } & \multirow{2}{*}{ No. of cases } & \multicolumn{3}{|c|}{ Grading of labeling index (\%) } \\
\hline & & $\mathrm{p} 53(\geq 15 \%)$ & & p21 $(\geq 5 \%)$ \\
\hline \multirow[t]{2}{*}{ Plexiform } & 16 & $(+) 7$ & & (+) 5 \\
\hline & & (-) 9 & & $(-) 11$ \\
\hline \multirow[t]{2}{*}{ Follicular } & 14 & $(+) 1$ & & $(+) 3$ \\
\hline & & $(-) 13-$ & & $(-) 11$ \\
\hline
\end{tabular}

Labeling-index: Positive cell/1000 tumor cells $\times 100(\%)$

p 53; $(-)<$ Labeling-index $15 \% \leq(+)$

p21; $(-)<$ Labeling-index $5 \% \leq(+)$

** Fisher's exact probability test $(\mathrm{p}=0.040)$

Significant differences: $\mathrm{p}<0.05$

cases $(37 \%)$ in the follicular type (Fig. 1O, P). In the stratified squamous epithelia (Fig. 1M), cells labeled with antip53 protein antibody were sparsely located in the parabasal layer, whereas many SCC cells exhibited p53-labeled nuclei (Fig. 1N). The labeling index of $\mathrm{p} 53$ protein in the neoplastic cells was $8.9 \pm 10.6 \%$ overall and was higher in the plexiform type $(12.5 \pm 13.1 \%)$ than in the follicular type $(4.7 \pm 5.1 \%)$ (Table 3 ). In grading the p53 protein labeling index as below and above $15 \%$ (Table 4), there were significantly more cases above $15 \%$ in the plexiform type ( 7 cases, $23 \%$ ) than in the follicular type ( 1 case, $3 \%)(\mathrm{p}=0.040)$.

The expression of $\mathrm{p} 21$ protein was recognized in 18 cases $(60 \%)$ overall, 8 cases $(27 \%)$ in the plexiform type and 10 cases $(33 \%)$ in the follicular type. The cells exhibiting p21 protein-labeled nuclei were distributed sparsely in the ameloblastoma (Fig. 1S, T). Many cells exhibiting p21 protein-labeled nuclei were observed in the squamous cell carcinoma (Fig. 1R), whereas they were not observed in the stratified squamous epithelia (Fig. 1Q). The labeling index of $\mathrm{p} 21$ protein in the neoplastic cells was $3.9 \pm 6.4 \%$ overall; $5.3 \pm 8.2 \%$ in the plexiform type and $2.3 \pm 3.5 \%$ in the follicular type (Table 3 ). In grading of the p21 protein labeling index as below and above 5\% (Table 4), there were significantly more cases above $5 \%$ in the plexiform type ( 5 cases, $17 \%$ ) than in the follicular type ( 3 case, $10 \%$ ).

The labeling indices of $\mathrm{p} 53$ protein and $\mathrm{p} 21$ protein were interrelated $(p=0.0067)$ (Table 5). In grading their indices it was demonstrated that $\mathrm{p} 53$ protein was expressed more, as ameloblastoma cells indicated higher labeling indices of PCNA, Ki-67 antigen and topoisomerase II $\alpha$ (Mann-Whitney's U-test, $\mathrm{p}<0.05$ ). However, the $\mathrm{p} 21$ protein did not exhibit higher labeling indices.

The ameloblastoma cells exhibited higher labeling indices of $\mathrm{p} 53$ protein and $\mathrm{p} 21$ protein in the mandible than those in the maxilla (Table 6).

\section{Discussion}

In this study, antibodies for PCNA, Ki-67 and topoisomerase II $\alpha$ were used to analyze proliferation of ameloblastoma cells $[2,6-8,12,14,18-20,22,28]$. PCNA has

Table 5. Relation between each antibodies

\begin{tabular}{lccccc}
\hline & PCNA & Ki-67 & Topo II $\alpha$ & p53 $(\geq 15 \%)$ & $\mathrm{p} 21(\geq 5 \%)$ \\
\hline PCNA & - & $0.0001^{*}$ & $\mathrm{NC}$ & $0.0005^{* *}$ & $0.0186^{* *}$ \\
Ki-67 & $0.0001^{*}$ & - & $\mathrm{NC}$ & $0.0021^{* *}$ & $\mathrm{NC}$ \\
Topo II & $\mathrm{NC}$ & $\mathrm{NC}$ & - & $0.0275^{* *}$ & $\mathrm{NC}$ \\
p53 $(\geq 15 \%)$ & $0.0005^{* *}$ & $0.0021^{* *}$ & $0.0275^{* *}$ & - & $0.0067^{*}$ \\
p21 $(\geq 5 \%)$ & $0.0186^{* *}$ & $\mathrm{NC}$ & $\mathrm{NC}$ & $0.0067^{*}$ & - \\
\hline
\end{tabular}

\footnotetext{
* Pearson's correlation coefficient $(\mathrm{p}<0.05)$

** Mann-Whitney's U-test $(\mathrm{p}<0.05)$

NC: No correlation
} 
Labeling index $(\%)$

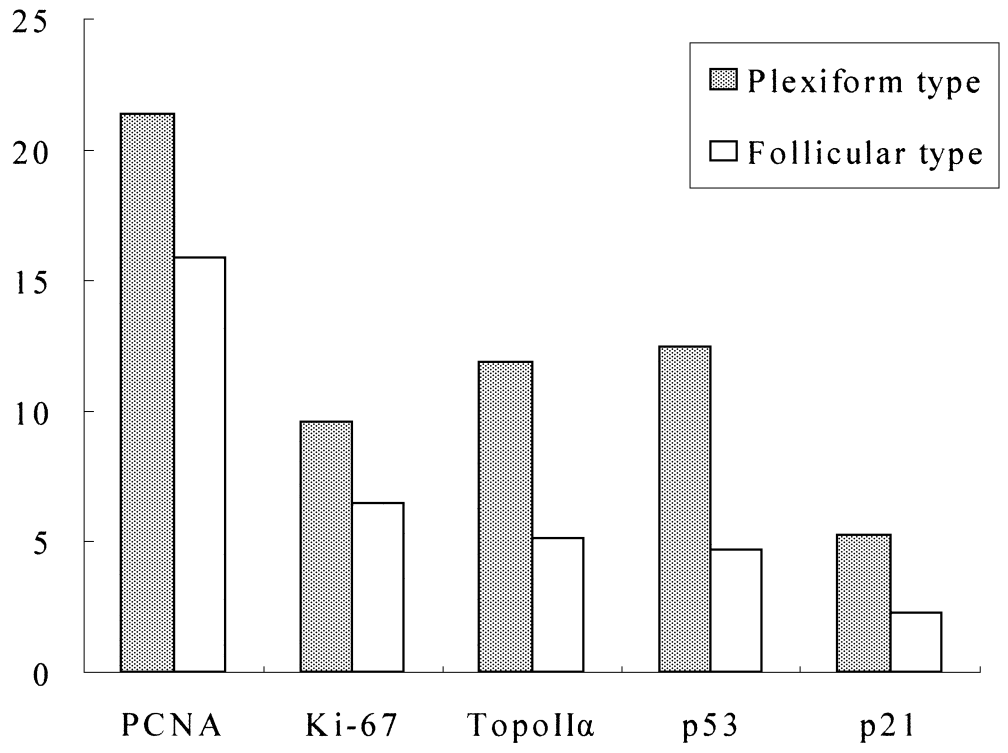

Antibodies
Fig. 2. Labeling indices obtained by proliferation cell markers and cell proliferating suppressor gene in ameloblastoma. Plexiform ameloblastomas exhibit higher labeling indices than follicular ameloblastomas for all antibodies.

Table 6. Labeling indices of clinicopathological factors in 30 patients with ameloblastoma

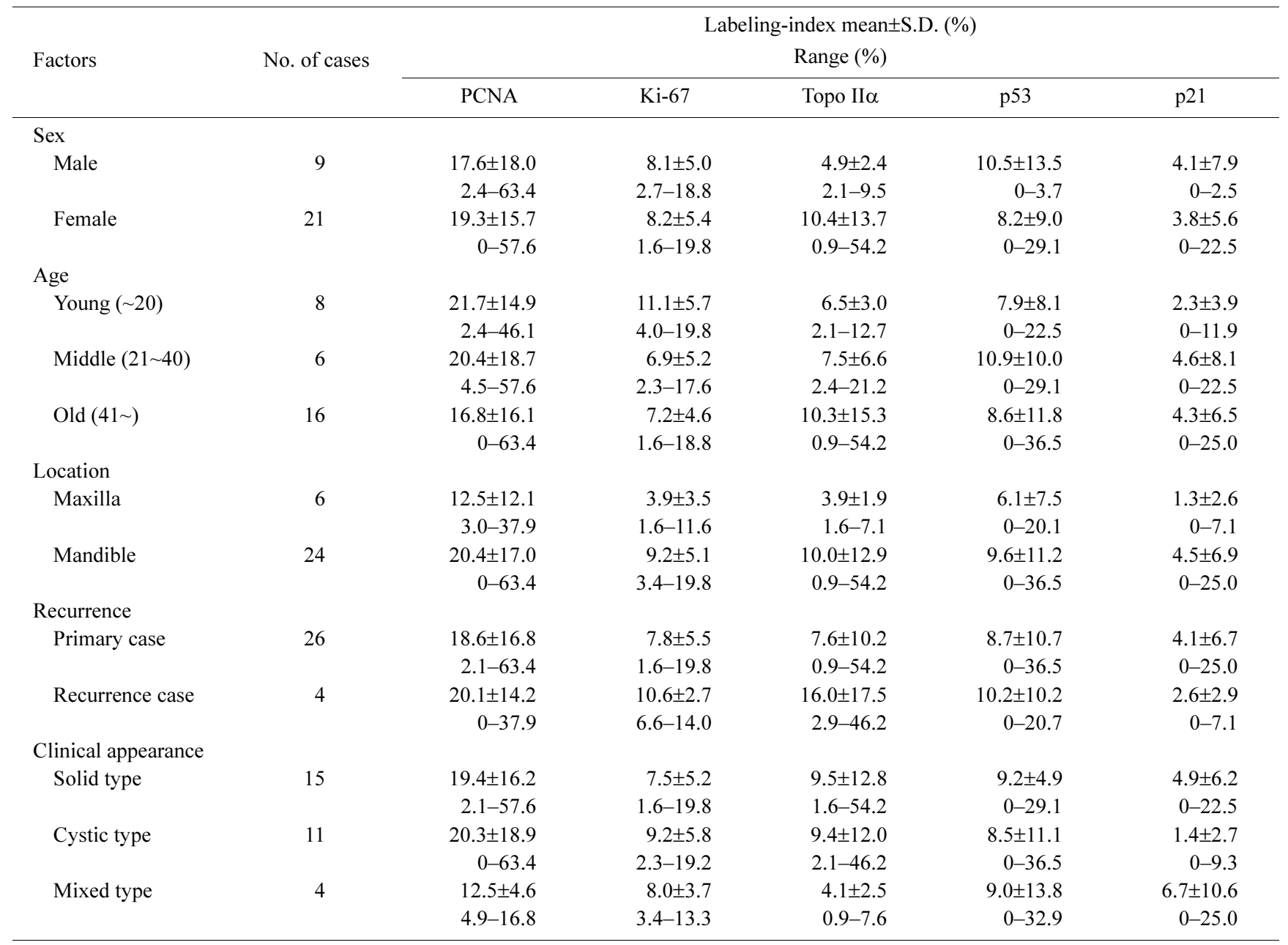

Labeling-index: Positive cell/1000 tumor cells $\times 100(\%)$ 
been used as a marker of proliferating cells, increasing to maximum during the $\mathrm{S}$ phase of the cell cycle [1, 15], although PCNA plays many roles in DNA duplication and DNA repair [27]. Regarding PCNA metabolism, the half-life of PCNA is longer than that of Ki-67 and topoisomerase II $\alpha$ [17]. Ki-67 antigen is a well-known marker of proliferating cells during the G1, S, G2 and M phases in the cell cycle, and is often applied to detect the fraction of proliferating cells in IHC [3-5, 25]. Topoisomerase II $\alpha$ is also a cell cycle-related protein and its expression in ameloblastomas has been reported by Kumamoto et al. [12] in proliferating cells expressing cyclin D1 and histone $\mathrm{H} 3$ mRNA. Using these antibodies in the present investigation, PCNA labeled many more nuclei than the Ki-67 antigen, although the labeling indices of PCNA and Ki-67 antigen were interrelated in the ameloblastoma. By contrast, topoisomerase II $\alpha$ was expressed in some parabasal cells in the almost-normal stratified squamous epithelia, where many parabasal cells were labeled with $\mathrm{Ki}-67$ antigen, suggesting that topoisomerase II $\alpha$ plays a role in DNA duplication, in the $\mathrm{S}$ phase of the cell cycle, along with the PCNA and Ki-67 antigen. However, the labeling index of topoisomerase II $\alpha$ did not correlate with those of PCNA and Ki-67. Thus, the occurrence of oncogenesis in ameloblastoma may induce disordered expression of topoisomerase II $\alpha$.

The proliferation activity of ameloblastoma cells has been investigated using IHC of PCNA and Ki-67. This study indicated that the labeling indices of PCNA, Ki-67 and topoisomerase II $\alpha$ were higher in the plexiform type than in the follicular type, as suggested by Hayashi et al. [6] and Piattelli et al. [20], but contradicted by Iwamoto et al. [7], Nakamura et al. [18], Li et al. [14], Sandra et al. [22] and Ong'uti et al. [19]. Although the palisading of marked tumor cells in the outer layer of the alveoli may give the impression of a follicular pattern even in the plexiform type, the histological features in the plexiform and follicular types were quite distinct. We considered that the reason for the diversely reported proliferation activity of ameloblastomas was attributable to the techniques of IHC [26] that increased the sensitivity to detect these antigens in the plexiform type. Furthermore, the polymer method, such as the ChemMate ENVISION/HRP employed in this study, is considered to be supersensitive for IHC. At present, it is now possible to obviously detect these antigens, unstained in sections of archival tissues that have been processed by so-called formalin methods. As reported previously, this study also demonstrated that recurrent ameloblastomas exhibited higher labeling indices of PCNA and Ki-67 antigen than primary cases and suggested the ability of these antigens in predicting the prognosis of ameloblastomas.

p53 is a cell-proliferation suppressor gene that encodes a 53-kDa phosphoprotein, which inhibits cell proliferation. p53 protein stimulates activation of the $\mathrm{p} 21$ gene, which in turn suppresses the kinase activity of G1 cyclin/cyclindependent kinase (Cdk) complexes and arrests the cell cycle at the G1 phase. As the expression of p53 protein was much more prominent in the parabasal layer of the almost- normal stratified squamous epithelia than $\mathrm{p} 21$ protein (Fig. $1 \mathrm{M}, \mathrm{Q})$, the interrelation between the labeling indices of $\mathrm{p} 53$ protein and $\mathrm{p} 21$ protein in the ameloblastoma suggested a close relationship between $\mathrm{p} 53$ protein and $\mathrm{p} 21$ protein, although the expression of p53 protein was prominent and indicated higher labeling indices in the ameloblastoma than p21 protein. It is well known that the proliferation suppressor gene is often mutated in neoplastic cells. In this study, by grading the labeling indices of the p53 and p21 proteins under and above $15 \%$ and $5 \%$, respectively, it was demonstrated that there was a significant correlation between the expression of p53 protein and the expression of the proliferation-related markers, such as PCNA, Ki-67 antigen and topoisomerase II $\alpha$, suggesting the over-expression of $\mathrm{p} 53$ proteins in relation to the true neoplastic growth of ameloblastoma, although Sandra et al. [23] reported a p53 gene mutation in a small number of ameloblastoma. As p53 protein, p21 protein might be expressed below the level of detection of the IHC employed in this study.

In this study, we demonstrated that the expression of p53 and p21 proteins was higher in the plexiform type than in the follicular type. The function of $\mathrm{p} 53$ protein in DNA damage might explain the apoptotic cells that were reported in recent studies of ameloblastoma [11]. To further elucidate the relation of the expression of p53 and p21 proteins with apoptotic cells, combined studies are urged.

Consequently, the present IHC study has clearly demonstrated that the plexiform ameloblastoma has higher proliferating activity and malignant potentiality as neoplastic cells than the follicular ameloblastoma.

\section{References}

1. Bravo, R., Frank, R., Blundell, P. A. and Macdonald-Bravo, H. (1987) Cyclin/PCNA is the auxiliary protein of DNA polymerase-delta. Nature 326; 515-517.

2. Funaoka, K., Arisue, M., Kobayashi, I., Iizuka, T., Kohgo, T., Amemiya, A. and Totsuka, Y. (1996) Immunohistochemical detection of proliferating cell nuclear antigen (PCNA) in 23 cases of ameloblastoma. Eur. J. Cancer B. Oral Oncol. 32B; 328-332.

3. Gerdes, J., Schwab, U., Lemke, H. and Stein, H. (1983) Production of a mouse monoclonal antibody reactive with a human nuclear antigen associated with cell proliferation. Int. J. Cancer $31 ; 13-20$.

4. Gerdes, J., Lemke, H., Baisch, H., Wacker, H. H., Schwab, U. and Stein, H. (1984) Cell cycle analysis of a cell proliferationassociated human nuclear antigen defined by the monoclonal antibody Ki-67. J. Immunol. 133; 1710-1715.

5. Gerdes, J., Li, L., Schlueter, C., Duchrow, M., Wohlenberg, C., Gerlach, C., Stahmer, I., Kloth, S., Brandt, E. and Flad, H. D. (1991) Immunobiochemical and molecular biologic characterization of the cell proliferation-associated nuclear antigen that is defined by monoclonal antibody Ki-67. Am. J. Pathol. 138; 867873.

6. Hayashi, K., Nagatsuka, H., Inoue, M. and Nagai, N. (1995) Immunohistochemical study of ameloblastoma and malignant ameloblastoma by monoclonal antibody against proliferating cell nuclear antigen. J. Jpn. Stomatol. Soc. 44; 7-13.

7. Iwamoto, H., Sano, K. and Inokuchi, T. (1998) Immunohistochemical study on ameloblastoma-Comparison between histological type and growth potential. J. Jpn. Stomatol. Soc. 47; 471- 
474.

8. Kim, J. and Yook, J. I. (1994) Immunohistochemical study on proliferating cell nuclear antigen expression in ameloblastomas. Eur. J. Cancer B. Oral Oncol. 30B; 126-131.

9. Kinjo, T., Kamiyama, K., Chinen, K., Arasaki, A. and Iwamasa, T. (2004) Possible factors related to phenotype change from adenocarcinoma to squamous cell carcinoma. Acta Histochem. Cytochem. 37; 7-14.

10. Kramer, I. R. H., Pindborg, J. J. and Shear, M. (1992) WHO Histological Typing of Odontogenic Tumours. Springer-Verlag, Berlin, pp. 11-14.

11. Kumamoto, H. (1997) Detection of apotosis-related factors and apoptotic cells in ameloblastomas: analysis by immunohistochemistry and an in situ DNA nick end-labeling method. J. Oral Pathol. Med. 26; 419-425.

12. Kumamoto, H., Kimi, K. and Ooya, K. (2001) Detection of cell cycle-related factors in ameloblastomas. J. Oral Pathol. Med. 30; 309-315.

13. Leong, A. S.-Y. and Leong, F. J. W.-M. (2002) Microwave-stimulated antigen retrieval-An Update. Acta Histochem. Cytochem. $35 ; 367-374$

14. Li, T. J., Browne, R. M. and Matthews, J. B. (1995) Expression of proliferating cell nuclear antigen (PCNA) and Ki-67 in unicystic ameloblastoma. Histopathology 26; 219-228.

15. Mathews, M. B., Bernstein, R. M., Franza, B. R. and Garrels, J. I. (1984) Identity of the proliferating cell nuclear antigen and cyclin. Nature 309; 374-376.

16. Meer, S., Galpin, J. S., Altini, M., Coleman, H. and Ali, H. (2003) Proliferating cell nuclear antigen and Ki-67 immunoreactivity in ameloblastoma. Oral Surg. Oral Med. Oral Pathol. Oral Radiol. Endod. 95; 213-221.

17. Morris, G. F. and Mathews, M. B. (1989) Regulation of proliferating cell nuclear antigen during the cell cycle. J. Biol. Chem. $264 ; 13856-13864$

18. Nakamura, N., Higuchi, Y., Sasaguri, M., Harada, H. and Tashiro, H. (1994) Immunohistochemical evaluation on expres- sion of proliferating cell nuclear antigen in ameloblastoma. Jpn J. Oral Maxillofac. Surg. 40; 509-513.

19. Ong'uti, M. N., Cruchley, A. T., Howells, G. L. and Williams, D. M. (1997) Ki-67 antigen in ameloblastomas: correlation with clinical and histological parameters in 54 cases from Kenya. Int. J. Oral Maxillofac. Surg. 26;376-379.

20. Piattelli, A., Fioroni, M., Santinelli, A. and Rubini, C. (1998) Expression of proliferating cell nuclear antigen in ameloblastomas and odontogenic cysts. Oral Oncol. 34; 408-412.

21. Reichart, P. A., Philipsen, H. P. and Sonner, S. (1995) Ameloblastoma: biological profile of 3677 cases. Eur. J. Cancer B. Oral Oncol. 31B; 86-99.

22. Sandra, F., Mitsuyasu, T., Nakamura, N., Shiratsuchi, Y. and Ohishi, M. (2001) Immunohistochemical evaluation of PCNA and Ki-67 in ameloblastoma. Oral Oncol. 37; 193-198.

23. Sandra, F., Nakamura, N., Kanematsu, T., Hirata, M. and Ohishi, M. (2002) The role of MDM2 in the proliferative actinity of ameloblastoma. Oral Oncol. 38; 153-157.

24. Sandros, J., Heikinheimo, K., Happonen, R. P. and Stenman, G. (1991) Expression of p21RAS in odontogenic tumors. APMIS 99; $15-20$.

25. Scholzen, T. and Gerdes, J. (2000) The Ki-67 protein: from the known and the unknown. J. Cell. Physiol. 182; 311-322.

26. Shi, S. R., Cote, R. J. and Taylor, C. R. (2001) Antigen retrieval techniques: current perspectives. J. Histochem. Cytochem. 49; 931-937.

27. Shivji, K. K., Kenny, M. K. and Wood, R. D. (1992) Proliferating cell nuclear antigen (PCNA) is required for DNA excision repair. Cell 69; 367-374.

28. Slootweg, P. J. (1995) P53 protein and Ki-67 reactivity in epithelial odontogenic lesions. An immunohistochemical study. J. Oral Pathol. Med. 24; 393-397.

29. Yamamoto, K., Yoneda, K., Yamamoto, T., Ueta, E. and Osaki, T. (1995) An immunohistochemical study of odontogenic mixed tumors. Eur. J. Cancer B. Oral Oncol. 31B; 122-128. 